\title{
Hot Corrosion \& Erosion Problems in Coal Based Power Plants in India and Possible Solutions - A Review
}

\author{
Vikas Chawla $^{\mathrm{a} *}$, Amita Chawla ${ }^{\mathrm{b}}$, D. Puri ${ }^{\mathrm{c}}$, S. Prakash ${ }^{\mathrm{c}}$, Prema G. Gurbuxani ${ }^{\mathrm{d}}$ and Buta \\ Singh Sidhu ${ }^{e}$ \\ ${ }^{a}$ Mechanical Engineering Department, F.C.E.T. Ferozepur-152002, India \\ ${ }^{\mathrm{b}}$ Chemistry Department, Govt. Brijindra College,Faridkot-151203,India \\ ${ }^{\mathrm{c}}$ Metallurgical \& Materials Engineering Department, I.I.T. Roorkee, Roorkee-247667, India \\ ${ }^{\mathrm{d}}$ Chemistry Department, Smt. C. H. M. College,Ulhasnagar-421003,India \\ ${ }^{\mathrm{e}}$ Dean (Academics), P.T.U., Jalandhar-144001,India \\ *Corresponding author: vikkydmt@iitr.ernet.com
}

\begin{abstract}
Hot corrosion and erosion are recognized as serious problems in coal based power generation plants in India. The coal used in Indian power stations has large amounts of ash (about 50\%) which contain abrasive mineral species such as hard quartz (up to 15\%) which increase the erosion propensity of coal. Hot corrosion and erosion in boilers and related components are responsible for huge losses, both direct and indirect, in power generation. An understanding of these problems and thus to develop suitable protective system is essential for maximizing the utilization of such components. These problems can be prevented by either changing the material or altering the environment or by separating the component surface from the environment. Corrosion prevention by the use of coatings for separating material from the environment is gaining importance in surface engineering.
\end{abstract}

Keywords: Hot corrosion, erosion, Thermal spraying (TS), Physical vapour deposition (PVD), Chemical vapour deposition (CVD), Nanostructured coatings.

\section{INTRODUCTION}

The attainment of high temperatures has been important in the development of civilization for many countries [1]. Structural materials in many front-line high technology areas have to operate under extreme conditions of temperature, pressure and corrosive environment [2]. So, Materials 
degradation at high temperatures is a serious problem in several high tech industries. Gas turbines in aircraft, fossil fueled power plants, refineries, and petrochemical industries, and heating elements for high temperature furnaces are some examples where corrosion limits their use or reduces their life, considerably affecting the efficiency [1].

World-wide, the majority of electricity is generated in coal-fired thermal plants, in which the coal is burned to boil water: the steam so produced is expanded through a turbine, which turns a generator [3]. The steam at the low pressure exit end of the turbine is condensed and returned to the boiler.

Coal is a complex and relatively dirty fuel that contains varying amount of sulfur and a substantial fraction of non combustible mineral constituents, commonly called ash [4]. The coal used in Indian power stations has large amounts of ash (about 50\%), which contain abrasive mineral species such as hard quartz (up to $15 \%$ ), which increase the erosion propensity of coal [5].

The vast technical literature available is evidence that corrosion and deposits on the fireside of boiler surfaces or in gas turbines represent important problems [6]. Metals and alloys may experience accelerated oxidation when their surfaces are coated by a thin film of fused salt in an oxidizing gas. This mode of attack is called hot corrosion, and the most dominant salt involved is $\mathrm{Na}_{2} \mathrm{SO}_{4}$ [7]. High temperature degradation is one of the main failure modes of hot-section components in the gas turbines, so an understanding of this high temperature oxidation is very necessary [8].

Solid particle erosion (SPE) is a serious problem for the electric power industry, costing an estimated US $\$ 150$ million a year in lost efficiency, forced outages, and repair costs [9]. Erosive, high temperature wear of heat exchanger tubes and other structural materials in coal-fired boilers are recognized as being the main cause of downtime at power-generating plants, which could account for $50-75 \%$ of their total arrest time. Maintenance costs for replacing broken tubes in the same installations are also very high, and can be estimated at up to $54 \%$ of the total production costs.

High temperature oxidation and erosion by the impact of fly ashes and unburned carbon particles are the main problems to be solved in these applications. Therefore, the development of wear and high temperature oxidation protection systems in industrial boilers is a very important topic from both engineering and an economic perspective [10]. 


\section{COAL FIRED POWER PLANTS}

The availability of electrical power and the development of million of devices that use it have made electricity the energy of choice in contemporary industrial societies. It is estimated that in the United States approximately $70 \%$ of the electricity is produced in fossil power plants, $15 \%$ in nuclear power plants, $12 \%$ in hydraulic power plants and the remainder from other types of sources [11]. In any event, the fossil fuel power plant is and will continue to be the mainstay of electric power production.

The fossil fuel employed in a steam turbine plant can be pulverized coal (PC), oil, or natural gas. Of these, coal is the most abundant and hence the most commonly used fuel for steam turbine plants, while gas turbine plants generally employ oil and natural gas. Figure 1 shows the arrangement of the various elements of a PC fossil plant. Here, water is first preheated to a relatively low temperature in feed water heaters and pumped into tubes contained in a boiler. The water is heated to steam by the heat of combustion of pulverized coal in the boiler and then superheated. Superheated and pressurized steam is then allowed to expand in a high-pressure (HP) steam turbine and causes rotation of the turbine shaft. The outlet steam from the HP turbine may once again be reheated and made to expand through an intermediate pressure (IP) turbine and then through a low-pressure (LP) turbine. The turbine shafts are all connected to one or more generator shafts which in turn rotate and convert the mechanical energy of rotation into electrical energy in the generator. The exit steam from the LP turbine is condensed in the condenser and is once again fed back to the boiler through the feed water heater and pumps. A closed loop of the water and steam is thus maintained.

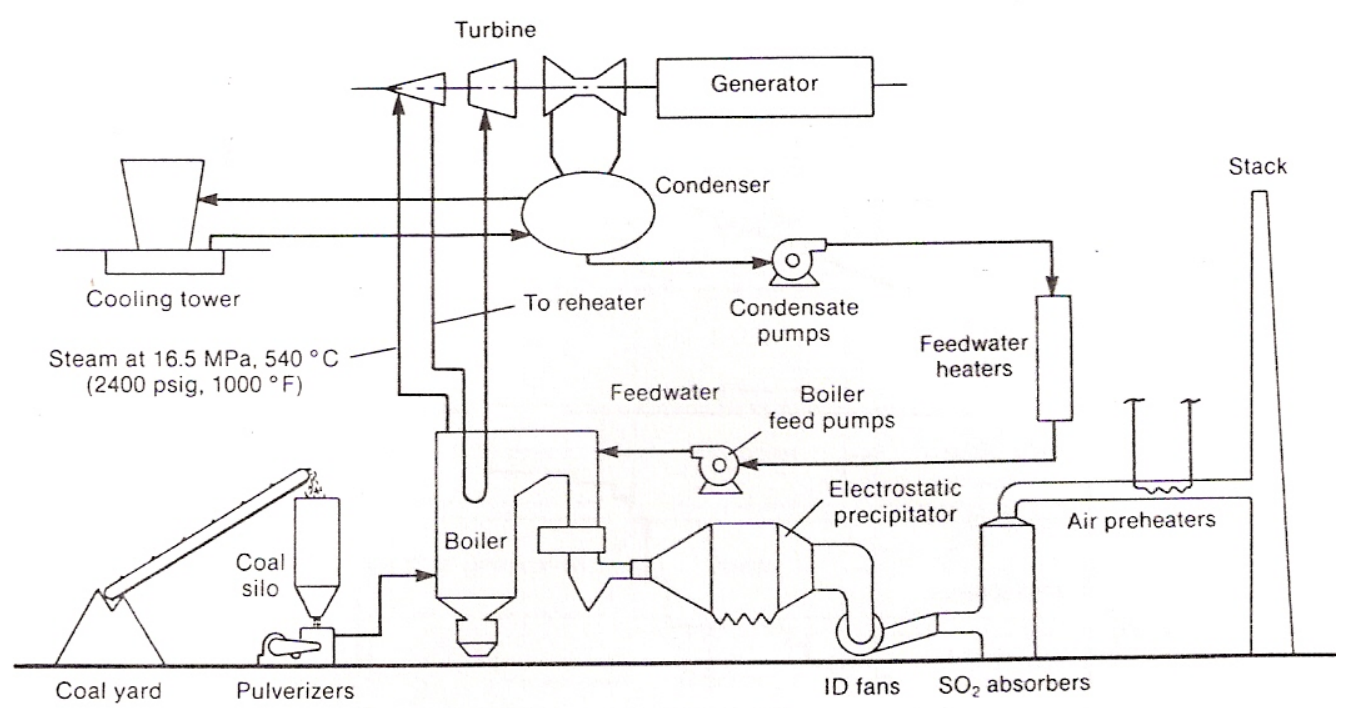

Figure 1: Schematic diagram of a coal-fired steam power plant [11]. 


\subsection{Indian Coal Contents and its Combustion}

Coal gasification systems operate at temperature of up to $2000 \mathrm{~F}\left(1093^{\circ} \mathrm{C}\right)$ and at a pressure of up to $100 \mathrm{~atm}$ depending on the specific process and the product, coal gas generates the greatest problems.

In addition to hydrogen and carbon-containing gaseous species, there are many undesirable species including sulphides, sulphites, sulphates, ammonia, cyanides, volatilised oils, phenols and aggressive trace elements such as potassium, sodium, vanadium and lead [12].

The coal used in Indian power stations has large amounts of ash (about 50\%), which contain abrasive mineral species such as hard quartz (up to 15\%), which increase the erosion propensity of coal [3]. The Indian coal proved to be exceptional in that they had significant amounts of alkali feldspars, $(\mathrm{K}, \mathrm{Na}) \mathrm{AlSi}_{3} \mathrm{O}_{8}$, and a garnet, minerals usually thought of as trace components of a coal. The garnets found in the Indian coals were found to follow the general formula $(\mathrm{Mg}$, $\left.\mathrm{Fe}^{2+}\right)_{3} \mathrm{Al}_{2} \mathrm{Si}_{3} \mathrm{O}_{12}$. J.J. Wells et al [13] have studied the Ash content, major minerals and trace materials in 10 coals and found the maximum ash content in Indian coal. Table: 1 indicate the Indian coal with dry ash content and mineral matter [13]. Further the coal analysis data collected from Guru Gobind Singh Thermal Plant, Ropar (Punjab), is presented in Table-2. The ash and flue gases analysis of Guru Nanak Dev Thermal Plant, Bathinda (Punjab), is presented in Table 3, which also indicates the presence of these constituents.

Table 1: The ash content and mineral matter in the suite of coals [13]

\begin{tabular}{|l|l|l|l|}
\hline Coal & $\begin{array}{l}\text { Ash Content } \\
(\mathbf{W t \% )} \mathbf{d a b}\end{array}$ & Major minerals & Trace minerals \\
\hline $\begin{array}{l}\text { Indian coal } \\
\text { A }\end{array}$ & 46.7 & $\begin{array}{l}\text { Quartz, muscovite, illitic } \\
\text { clay, Kaolinite, siderite }\end{array}$ & $\begin{array}{l}\text { Barites, feldspar, ilmenite, } \\
\text { pyrite, rutile, zircon }\end{array}$ \\
\hline $\begin{array}{l}\text { Indian coal } \\
\text { B }\end{array}$ & 30.3 & $\begin{array}{l}\text { Quartz, feldspar, illitic clay, } \\
\text { kaolinite, muscovite, siderite }\end{array}$ & $\begin{array}{l}\text { Apatite, garnet, ilmenite, } \\
\text { monazite, rutile, zircon }\end{array}$ \\
\hline $\begin{array}{l}\text { Indian coal } \\
\text { C }\end{array}$ & 45.6 & $\begin{array}{l}\text { Quartz, feldspar, garnet, } \\
\text { illitic clay, muscovite, } \\
\text { kaolinite }\end{array}$ & $\begin{array}{l}\text { Apatite, ilmenite, monazite, } \\
\text { pyrite, rutile, zircon }\end{array}$ \\
\hline
\end{tabular}


Table 2: Coal Analysis data

\begin{tabular}{|l|l|}
\hline Constituent & $\begin{array}{l}\text { Wt. } \\
\text { \%age }\end{array}$ \\
\hline $\begin{array}{l}\text { Total moisture } \\
\text { (inherent }+ \text { surface) }\end{array}$ & 10.43 \\
\hline Inherent moisture & 7.55 \\
\hline Ash & 34.74 \\
\hline $\begin{array}{l}\text { Ash on fire basis } \\
\text { (actual) }\end{array}$ & 33.64 \\
\hline Volatile metal & 21.59 \\
\hline $\begin{array}{l}\text { GC } \\
\text { calorific value) in } \\
\text { Kcal/kg }\end{array}$ & 4187 \\
\hline $\begin{array}{l}\text { GC } C_{\mathrm{v}} \text { on fire basis in } \\
\text { Kcal/kg }\end{array}$ & 4055 \\
\hline Net $\mathrm{GC}_{\mathrm{v}}$ in Kcal/kg & 3834 \\
\hline $\begin{array}{l}\text { Unburnt carbon in } \\
\text { fly ash }\end{array}$ & 1.35 \\
\hline $\begin{array}{l}\text { Unburnt carbon in } \\
\text { bottom ash }\end{array}$ & 5.75 \\
\hline
\end{tabular}

Table-3: Chemical analysis of ash and flue gases inside the boiler.

\begin{tabular}{|c|c|c|c|}
\hline \multicolumn{2}{|l|}{ Ash } & \multirow{2}{*}{$\begin{array}{l}\text { Flue Gases } \\
\text { (Volumetri } \\
\mathrm{m}^{3} / \mathrm{sec} \text { ) }\end{array}$} & \multirow[b]{2}{*}{ flow, 231} \\
\hline Constituent & $\begin{array}{l}\text { Wt. } \\
\text { \%age }\end{array}$ & & \\
\hline Silica & 54.70 & Constituent & $\begin{array}{l}\text { Value relative } \\
\text { to flue gases }\end{array}$ \\
\hline $\mathrm{Fe}_{2} \mathrm{O}_{3}$ & 5.18 & $\mathrm{SO}_{\mathrm{x}}$ & $236 \mathrm{mg} / \mathrm{m}^{3}$ \\
\hline $\begin{array}{l}\mathrm{Al}_{2} \mathrm{O}_{3^{-}} \\
\mathrm{Fe}_{2} \mathrm{O}_{3} / \mathrm{Al}_{2} \mathrm{O}_{3}\end{array}$ & 29.56 & $\mathrm{NO}_{\mathrm{x}}$ & $1004 \mu \mathrm{g} / \mathrm{m}^{3}$ \\
\hline Calcium oxide & 1.48 & $\mathrm{CO}_{2}$ & $12 \%$ \\
\hline $\begin{array}{l}\text { Magnesium } \\
\text { oxide }\end{array}$ & 1.45 & $\mathrm{O}_{2}$ & $7 \%$ \\
\hline $\mathrm{SO}_{3}$ & 0.23 & \multirow{4}{*}{\multicolumn{2}{|c|}{$\begin{array}{l}40 \% \text { excess air was } \\
\text { supplied to the } \\
\text { boiler for the combustion of } \\
\text { coal. }\end{array}$}} \\
\hline $\mathrm{Na}_{2} \mathrm{O}$ & 0.34 & & \\
\hline $\mathrm{K}_{2} \mathrm{O}$ & 1.35 & & \\
\hline Ignition loss & 4.31 & & \\
\hline
\end{tabular}


The corrosive nature of the gaseous environments, which contain oxygen, sulfur, and carbon, may cause rapid material degradation and result in the premature failure of components [14]. Combustion of coal generates very corrosive media particularly near the superheater tubes of the boilers. In the boiler tubes suffering severe fireside corrosion, sulphate salts concentrate at the deposit/scale interface and become partially fused since these salts contain alkali metals of sodium and potassium [15]. In the combustion systems, much of the sodium and potassium is volatized from the mineral matters in the flame to form $\mathrm{Na}_{2} \mathrm{O}$ and $\mathrm{K}_{2} \mathrm{O}$ vapours.

The sulphur released from the coal, forms $\mathrm{SO}_{2}$ with a minor amount of $\mathrm{SO}_{3}$ and reacts with the volatilized alkalis to form $\mathrm{Na}_{2} \mathrm{SO}_{4}$ vapours, which then condense together with fly ash on the pendant superheater and reheater tubes in the boiler.

The vast technical literature available is evidence that corrosion and deposits on the fireside of boiler surfaces or in gas turbines represent important problems [6]. When a comparison is made between the amount of ash collected in a boiler or a gas turbine, in the form of deposits, and the total amount of ash released during combustion, the conclusion is clear that most of the ash passes through the unit. For particles to collect on boiler surfaces or blade surfaces, they must first be brought close to the surface itself and be of the proper size. This can be ascribed to physical phenomenon involving the reaction of particles to the forces to which they are subjected within the stream of gases passing near the surfaces [6].

A particle may hit and then rebound from the surface. If it hits or rubs the surface with sufficient force, erosion will result. On the other hand, if the particle is captured physically or chemically by the surface, a deposit is initiated whose growth appears aerodynamically inevitable. Because of high temperatures, reactions can then take place between the various particles deposited, and also with the gases passing nearby, particularly $\mathrm{SO}_{3}$ and $\mathrm{SO}_{2}$. The resulting compounds may then react, by diffusion, with the metal structure on which they are attached and cause accelerated corrosion [6].

\section{HOT CORROSION}

Oxidation is a type of corrosion involving the reaction between a metal and air or oxygen at high temperature in the absence of water or an aqueous phase. It is also called dry-corrosion. The rate of oxidation of a metal at high temperature depends on the nature of the oxide layer that forms on the surface of metal [16]. Metals and alloys may experience accelerated oxidation when their surfaces are coated by a thin film of fused salt in an oxidizing gas. This mode of attack is called hot corrosion.

Hot corrosion was first recognized as a serious problem in the 1940s in connection with the degradation of fireside boiler tubes in coal-fired steam generating plant. Since then the problem has been observed in boilers, internal combustion engines, gas turbines, fluidized bed combustion and 
industrial waste incinerators [17]. But, hot corrosion became a topic of important and popular interest in the late 60 s as gas turbine engines of military aircraft suffered severe corrosion during Viet Nam conflict during operation over sea water [18]. Metallographic inspection of failed parts often showed sulfides of nickel and chromium, so the mechanism was initially called "sulfidation". However, studies by Goebel and Pettit [19] and by Bornstein and DeCrescente [19] showed that sulfide formation indeed resulted from the reaction of the metallic substrate with a thin film of fused salt of sodium sulfate base, the phenomenon has been renamed "hot corrosion" [17].

Thus, hot corrosion may be defined as accelerated corrosion, resulting from the presence of salt contaminants such as $\mathrm{Na}_{2} \mathrm{SO}_{4}, \mathrm{NaCl}$, and $\mathrm{V}_{2} \mathrm{O}_{5}$ that combine to form molten deposits, which damage the protective surface oxides [20].

\subsection{General Classification of Hot Corrosion}

Hot corrosion is often divided into two forms of attack: Type I or High temperature hot corrosion (HTHC) above about $900^{\circ} \mathrm{C}$ where pure sodium sulfate is above its melting temperature, and Type II or Low temperature hot corrosion (LTHC), between about $700^{\circ} \mathrm{C}-750^{\circ} \mathrm{C}$ where a liquid salt phase is only formed because of significant dissolution of some corrosion products [18]. Various parameters may affect the development of these two forms, including alloy composition and thermo-mechanical condition, contaminant composition and flux rate, temperature and temperature cycles, gas composition and velocity, and erosion processes.

\subsection{Mechanism of Hot Corrosion}

Several mechanisms have been suggested to explain the process of hot corrosion [21]. The hot corrosion degradation process of the superalloys usually consists of two stages [22]:

1. An initiation stage during which the alloys behave much as they would have behaved in the absence of the deposits and

2. A propagation stage where the deposits cause the protective properties of the oxide scales to become significantly different then those that they would have been had no deposit been present.

Khana et al. [17], in their review of degradation of materials under hot corrosion conditions , stated that corrosion-resistant alloys depend on selective oxidation to form the dense, compact protective scales of $\mathrm{Cr}_{2} \mathrm{O}_{3}$ and $\mathrm{Al}_{2} \mathrm{O}_{3}$ for their resistance. During hot corrosion a degradation sequence consisting of the eventual displacement of a more protective reaction product barrier by a less protective product is usually followed. The hot corrosion degradation sequence is not clearly evident, and the time for which the protective scales are stable beneath the salt layer is influenced by a number of factors, which affects the initiation of hot corrosion. The propagation stage of the hot corrosion sequence is the stage for which the superalloy must be removed from 
service since this stage always has much larger corrosion rates than for the same superalloy in the initiation stage [19].

\section{EROSION}

Solid particle erosion (SPE) is the progressive loss of original material from a solid surface due to mechanical interaction between that surface and solid particles. Erosion is a serious problem in many engineering systems, including steam and jet turbines, pipelines and valves used in slurry transportation of matter, and fluidized bed combustion systems[23]. Solid particle erosion (SPE) is a serious problem for the electric power industry, costing an estimated US\$150million a year in lost efficiency, forced outages, and repair costs [24]. Erosive, high temperature wear of heat exchanger tubes and other structural materials in coal-fired boilers are recognized as being the main cause of downtime at power generating plants, which could account for $50-75 \%$ of their total arrest time [10]. Maintenance costs for replacing broken tubes in the same installations are also very high, and can be estimated up to $54 \%$ of the total production cost.

High temperature oxidation and erosion by the impact of fly ashes and unburned carbon particles are the main problems to be solved in these applications, especially in those regions where component surface temperature is above $600^{\circ} \mathrm{C}$. Therefore, the development of wear and high temperature oxidation protection systems in industrial boilers is a very important topic from both engineering and an economic perspective [10]. Erosion-corrosion at high temperature is a field within high temperature corrosion that is growing in importance [25]. Degradation of materials is a function of many parameters. These are normally classified in terms of properties of the particle (size, shape, velocity, impact angle, hardness), target (hardness, ductility, corrosion resistance) and the environment (temperature, partial pressure of the gaseous environments) [26].

A few different types of erosion-corrosion behavior are frequently observed. The model by Kang et al. [25], describes four regimes, which were assigned "erosion of oxide only", "erosionenhanced oxidation", "oxidation affected erosion", and "erosion of metal only". The order follows that of increasing erosion and decreasing oxidation rate.

\section{PREVENTIVE MEASURES AGAINST HOT CORROSION AND EROSION}

A case study reported by Prakash et. al. [27] pertaining to a coal fired boiler of a power plant where out of 89 failure occurring in one year duration, 50 failures were found to be due to hot corrosion and erosion by ash. Material losses due to erosion and corrosion are the major problems in many industries. Corrosion and its associated losses can not be eliminated completely. However, 25 to $30 \%$ of annual corrosion related costs could be saved with the use of optimum corrosion preventive and control strategies. These facts emphasize the need to develop more and more corrosion resistant materials for such applications. Therefore, the development 
of wear and high temperature oxidation protection systems in industrial boilers is a very important topic from both engineering and an economic perspective [10].

The option to use low grade fuel limits the improvement in hot corrosion and erosion environment. In that case hot corrosion preventive methods to the existing environment are (a) change of metal i.e. use of superalloy (b) use of inhibitors and (c) use of coatings. Regarding change of metal or use of super alloy, alloying elements which can improve the hot corrosion resistance of materials such as $\mathrm{Cr}$, $\mathrm{Al}$, etc., often have a negative effect on the mechanical properties in high temperature environments and are expensive [28].

Regarding use of inhibitor, addition of an organic inhibitor (e.g. pyridines, pyrimidines, quinolines) is sufficient to mitigate corrosion of metals in many corrosive media [29]. An inhibitor is a chemical substance or combination of substances that, when present in the environment, prevents or reduces corrosion without significant reaction with the components of the environment. The application of inhibitors must be viewed with caution by the user because inhibitors may afford excellent protection for one metal in a specific system but can aggravate corrosion for some other metal in same system. However, these inhibitors have shown only limited success due to solubility and/or thermal stability problems in high -temperature, concentrated salt solutions [29].

Increasingly greater demand imposed on materials makes it more difficult or, at the current stage of development, even impossible to combine the different properties required in one single material. Therefore, a composite system of a base material providing the necessary mechanical strength with a protective surface layer different in structure and/or chemical composition and supplied by a surface treatment can be an optimum choice in combining material properties.

Single materials are at their upper performance limits in all fields and coatings offer a way to extend these limits [30]. One possible way to cope with these problems is by using thin wear and oxidation resistant coatings with good thermal conductivities [10].

\subsection{Hot Corrosion \& Erosion Resistant Coatings}

The coating can be defined as a layer of material, formed naturally or synthetically or deposited artificially on the surface of an object made of another material, with the aim of obtaining required technical or decorative properties [14]. Coating technology is one of the more rapidly growing technologies in the field of materials. A combination of the development of materials specifically designed for erosion and corrosion resistance and the appropriate technique for the application of these materials, as a coating would be the optimum solution. 
Recent studies show that $80 \%$ of the total cost for the protection of metals, are related to coating applications [31]. Organic coatings cover a large part of this percentage ,but also metallic ones have a relatively big market. In fact, metallic coatings possesses together with good corrosion resistance, good aesthetics, brightness, and interesting mechanical properties such as hardness and wear resistance. In general, coating systems can be classified as either diffusion or overlay type, which are distinguished principally by the method of deposition and the structure of the resulting coating-substrate bond [4].

From a production point of view [15], three methods are in current use to deposit coatings, these being chemical vapour deposition (CVD), physical vapour deposition (PVD) and Plasma spraying. The CVD process comes under the category of Diffusion coatings, in which the coating material forms a chemical bond with the substrate. Whereas the PVD and Thermal spraying processes comes under the category of Overlay coatings, in which the desired material is placed over the substrate material [1].

\subsection{Thermal Spraying}

Thermal spraying is one of the most versatile hard facing techniques available for the application of coating materials used to protect components from abrasive wear, adhesive wear, erosive wear or surface fatigue and corrosion (such as that caused by oxidation or seawater) . Generally, any material which does not decompose, vaporize, sublimate, or dissociate on heating, can be thermally sprayed. Consequently a large class of metallic and nonmetallic materials (metals, alloys, ceramics, cermets, and polymers) can be deposited by thermal spraying. Heath et al (1997) [32] has summarized the thermal spray processes that have been considered to deposit the coatings, are enlisted below:

(1) Flame spraying with a powder or wire, (2) Electric arc wire spraying, (3) Plasma spraying, (4) Spray and fuse , (5) High Velocity Oxy-fuel (HVOF) spraying, (6) Detonation Gun.

The technique of thermal spraying has developed at a fast pace due to progress in the advancement of materials and modern coating technology. Plasma-sprayed ceramic coatings are used to protect metallic structural components from corrosion, wear and erosion, and to provide lubrication and thermal insulation [33]. In particular, coatings made of $\mathrm{Al}_{2} \mathrm{O}_{3}$ containing $13 \mathrm{wt} \%$ $\mathrm{TiO}_{2}\left(\mathrm{Al}_{2} \mathrm{O}_{3}-13 \mathrm{wt} \% \mathrm{TiO}_{2}\right)$ are commonly used to improve the wear-corrosion and erosion resistance of steel . In conventional plasma-spray processing of $\mathrm{Al}_{2} \mathrm{O}_{3}-13 \mathrm{wt} \% \mathrm{TiO}_{2}$ coatings, powder particles are injected into a plasma jet, causing them to melt into droplets that are propelled towards the substrate [33]. Solidification of the droplets stream onto the substrate as "splats" results into the buildup of the coating, typically $100-300 \mu \mathrm{m}$ thick. In order to obtain chemical homogeneity in the coating, the processing is performed at "hot" plasma conditions which ensure complete melting of the powder particles [29]. Plasma sprayed zirconia coatings as 
thermal barrier coatings have been applied to hot section components of gas engines to increase temperature capability Ni-base superalloys [34].

Buta Singh Sidhu et al. [35], while studying $\mathrm{Ni}_{3} \mathrm{Al}$ coatings on boiler tube steels through plasma spray process (where $\mathrm{Ni}-\mathrm{Cr}-\mathrm{Al}-\mathrm{Y}$ was used as a bond coat before applying $\mathrm{Ni}_{3} \mathrm{Al}$ coatings) observed that the $\mathrm{Ni}_{3} \mathrm{Al}$ coating was very effective in decreasing the corrosion rate in air and molten salt at $900^{\circ} \mathrm{C}$ in case of ASTM-SA210-Grade A1 and ASTM-SA213-T-11 type of steel where as the coating was least effective for ASTM-SA213-T-22 type of steel. Uncoated ASTMSA213-T-22 type of steel had shown very poor resistance to hot corrosion in molten salt environment and also indicated spalling of oxide scale. T.S. Sidhu et. al. [36] have evaluated the hot corrosion performance of high velocity oxy-fuel (HVOF) sprayed Ni-20Cr wire coating on a Ni-based super alloy for $1000 \mathrm{hrs}$ at $900^{\circ} \mathrm{C}$ under cyclic conditions in a coal-fired boiler. The HVOF sprayed Ni-20Cr coating was found to be effective in imparting hot corrosion resistance to Superni 75 in the actual working environment of a coal fired boiler as compared to the uncoated superalloy.

S.B. Mishra et. al.[37] have investigated plasma sprayed metallic coating of nickel-aluminide deposited on Fe-based superalloy. The coatings had shown better erosion resistance as compared to the uncoated samples. H.Singh et. al. [38] have studied high temperature oxidation behaviour of plasma sprayed $\mathrm{Ni}_{3} \mathrm{Al}$ coatings. In their investigation, $\mathrm{Ni}_{3} \mathrm{Al}$ powder was prepared by mechanical mixing of pure nickel and aluminium powders in a ball mill. Subsequently $\mathrm{Ni}_{3} \mathrm{Al}$ powder was deposited on three Ni-base superalloys: Superni 600, Superni 601 and Superni 718 and, one Fe-base superalloy, Superfer $800 \mathrm{H}$ by shrouded plasma spray process. Oxidation studies were conducted on the coated superalloys in air at $900 \circ \mathrm{C}$ under cyclic conditions for 50 cycles. Each cycle consisted of $1 \mathrm{~h}$ heating followed by $20 \mathrm{~min}$ of cooling in air. The thermogravimetric technique was used to approximate the kinetics of oxidation. All the coated superalloys nearly followed parabolic rate law of oxidation. X-ray diffraction, SEM/EDAX and EPMA techniques were used to analyze the oxidation products. The $\mathrm{Ni}_{3} \mathrm{Al}$ coating was found to be successful in maintaining its adherence to the superalloy substrates in all the cases. The oxide scales formed on the oxidised coated superalloys were found to be intact and spallation-free.

H.Singh et. al. [39] have studied hot corrosion performance of plasma sprayed coatings on a Febased superalloy. NiCrAlY, Ni-20Cr, $\mathrm{Ni}_{3} \mathrm{Al}$ and Stellite- 6 metallic coatings were deposited on a Fe-based Superalloy (32Ni-21Cr-0.3Al-0.3Ti-1.5Mn-1.0Si-0.1C-Bal Fe). NiCrAlY was used as bond coat in all the cases. Hot corrosion studies were conducted on uncoated as well as plasma spray coated superalloy specimens after exposure to molten salt at $900{ }^{\circ} \mathrm{C}$ under cyclic conditions. The coated specimens have shown better performance as compared to the uncoated specimens. 
Hazoor Singh Sidhu et. al. [40] have studied the role of HVOF coatings in improving hot corrosion resistance of ASTM-SA2 $10 \mathrm{GrA} 1$ steel in the presence of $\mathrm{Na}_{2} \mathrm{SO}_{4}-\mathrm{V}_{2} \mathrm{O}_{5}$ salt deposits. $\mathrm{Cr}_{2} \mathrm{C}_{3}-\mathrm{NiCr}$, NiCr, WC-Co and stellite- 6 metallic coatings were sprayed on ASTM SA-210 grade A1 steel by the HVOF process. Hot corrosion studies were conducted on the uncoated as well as HVOF sprayed specimens after exposure to molten salt at 900 -C under cyclic conditions. All these overlay coatings showed better resistance to hot corrosion as compared to that of uncoated steel. NiCr Coating was found to be most protective followed by $\mathrm{Cr}_{2} \mathrm{C}_{3}-\mathrm{NiCr}$ coating. WC-Co coating was least effective to protect the substrate steel. It is concluded that the formation of $\mathrm{Cr}_{2} \mathrm{O}_{3}, \mathrm{NiO}, \mathrm{NiCr}_{2} \mathrm{O}_{4}$, and $\mathrm{CoO}$ may contribute to the development of hot corrosion resistance in the coatings. The uncoated steel suffered corrosion in the form of intense spalling and peeling of the scale, which may be due to the formation of unprotective $\mathrm{Fe}_{2} \mathrm{O}_{3}$ oxide scale.

\subsection{Physical Vapor Deposition (PVD) Process}

In physical vapor deposition (PVD) process, the coating is deposited in vacuum by condensation from a flux of neutral or ionized atoms of metals [41]. Several PVD techniques are available for deposition of hard coatings. Among them, cathodic arc vapor (plasma or arc ion plating) deposition, magnetron sputtering (or sputter ion plating), and combined magnetron and arc processes are most widely used techniques to deposit titanium-aluminum based coatings.

PVD process is carried out in high vacuum at temperature between 150 and $500^{\circ} \mathrm{C}$. The high purity solid coating material (metals such as titanium, chromium \& aluminum) is either evaporated by heat or by bombardment with ions (sputtering). At the same time, a reactive gas (e.g. nitrogen or a gas containing carbon) is introduced; it forms a compound with the metal vapors and is deposited on the tools or components as a thin, highly adherent coating. In order to obtain a uniform coating thickness, the parts are rotated at uniform speed about several axes. The PVD techniques are widely used nowadays for improvement of the mechanical and other properties, of a broad range of engineering materials. Employing the PVD techniques for the deposition of coatings (namely multilayer coatings) ensures high corrosion and wear resistance. Besides, the ceramic nitrides, carbides present interesting colours which allow them to be used in decorative components (e.g., golden or a polished brass-like) [42].

In. S. Choi et.al. [43] have studied the corrosion behavior of TiAIN coatings prepared by PVD in a hydrofluoric gas atmosphere. TiAlN coating has one of the highest working temperature $\left(800^{\circ} \mathrm{C}\right)$ due to the surface being covered with a stable and passive aluminum oxide layer. When TiAlN is exposed to a HF gas atmosphere in working conditions, it reacts with $\mathrm{HF}$ and forms aluminum fluoride $\left(\mathrm{AlF}_{3}\right)$, which is chemically very stable to various corrosives such as acid, alkaline, alcohol and even HF. The process was quite successful and the coating exhibit better corrosion resistance. Sugehis Liscano et al. [44] have studied corrosion performance of duplex treatments based on plasma nitriding and PAPVD (Plasma Assisted physical vapour deposition) 
TiAlN coatings. The plasma nitrided substrates were coated commercially with BALINIT FUTURA NANO (TiAlN) coatings (Balzers, Inc., USA). The nanograined TiAlN coating has shown better results then the conventional counterpart.

R. Rodr' 1guez-Baracaldo et. al. [45] have studied the high temperature wear resistance of (TiAl)N PVD coating on untreated and gas nitrided AISI H13 steel with different heat treatments. The coated specimens have shown better wear resistance as compared to the uncoated specimens. W. kalss et al. [46] have studied some Ti and Al based coating and reported that the TiAl-based nitrides such as TiAlN and AlTiN were stable against oxidation up to temperatures about $800^{\circ} \mathrm{C}$. The coating with best oxidation resistance was $\mathrm{AlCrN}$. Even at $1100^{\circ} \mathrm{C}$ only a thin layer of about $150 \mathrm{~nm}$ in thickness could be observed. These coatings exhibit good thermal conductivity and better wear resistance. All coatings were deposited by a standard Balzers RCS cathodic arc coating machine.

\subsection{Chemical Vapor Deposition (CVD)}

Chemical Vapor Deposition (CVD) process is a versatile process that can be used to deposit nearly any metal as well as non metal such as carbon or silicon [1]. The first step is the production of metal vapours. Several chemical reactions can be used: thermal decomposition, pyrolysis, reduction, oxidation, nitridation etc. The main reaction is carried out in a separate reactor. The vapors thus formed are transferred to the coating chamber where the sample is mounted and maintained at high temperature. One of the limitations of the CVD is the high substrate temperature, which in many cases changes the microstructure of the substrate, and another is the size of specimens, often smaller parts are used due to limitation of chamber size.

S. Tsipas et. al. [47] have studied Al-Mn CVD-FBR protective coatings for hot corrosion application. In this study, new Al-Mn protective coatings were deposited by CVD-FBR on two ferritic steels (P-92 and HCM12). The CVD-FBR has been shown to be a powerful and effective technique to obtain Mn-containing aluminide coatings on ferritic steels. These coatings could be potential candidates for steam oxidation protection of ferritic steels.

F.J. P'ereza et. al. [48] have studied adhesion properties of aluminide coatings deposited via CVD in fluidised bed reactors_CVD-FBR/on AISI 304 stainless steel. The CVD-FBR technique has been shown to be a very interesting surface modification technology because aluminum diffusion coatings can be produced at lower temperatures and shorter times than by conventional pack cementation. Overall, the heat-treated aluminum coated AISI 304 specimens may find an application due to the combination of their toughness and the potential good corrosion properties. 


\subsection{Nanostructured Coatings}

Nanostructured coatings [17] composed of crystalline/amorphous nanophase mixture have recently attracted increasing interests in fundamental research and industrial applications, because of the possibilities of synthesizing a surface protection layer with unique physicalchemical properties that are often not attained in the bulk materials. Nanostructured materials as a new class of engineering materials with enhanced properties and structural length scale between 1 and $100 \mathrm{~nm}$.

Nanostructured ceramic coatings produced by Plasma sprayed processes are being developed for a wide variety of applications that required resistance to wear, erosion, corrosion, cracking and spallation, with improved properties. Pavitra Bansal et al [49] compared conventional and the nano $\mathrm{Al}_{2} \mathrm{O}_{3}-13 \mathrm{wt} \% \mathrm{TiO}_{2}$ plasma sprayed ceramic coatings on steel substrate. These new coatings (referred to as "nano", since they are derived from nanocrystalline powders) have improved abrasive wear-resistance and have a bond strength, as measured using the ASTM "pull" test, two times greater than that of the conventional plasma sprayed coatings, making the "nano" coatings technologically attractive.

Nano-materials are in their infancy of development but already show many processing and properties advantages over conventional coarse counterparts. Leon L.Shaw et al [50] studied the dependency of microstructure and properties of nanostructure and properties of nanostructured coatings on plasma spray conditions. $\mathrm{Al}_{2} \mathrm{O}_{3}-13 \mathrm{wt} \% \mathrm{TiO}_{2}$ coatings formed via a plasma spray approach using reconstituted nanosized $\mathrm{Al}_{2} \mathrm{O}_{3}$ and $\mathrm{TiO}_{2}$ powder. Wear test suggest that the coating produced from nanopowder feedstock could have better wear resistance than the coatings produced using commercial coarse-grained powders. Chuanxian Ding et al. [51] have investigated the plasma sprayed nanostructured zirconia coatings for wear resistance. The plasma sprayed nanostructured zirconia coatings reported possess a higher wear resistance then their conventional counter parts. The higher wear resistance of the nanostructured coatings is attributed to their optimized microstructure and improved micro-hardness.

L. Leblanc [52] has evaluated micro-structural as well as abrasion and sliding wear properties of APS (Atmospheric plasma spraying) and VPS (Vacuum plasma spraying) sprayed $\mathrm{Al}_{2} \mathrm{O}_{3}$ $13 \mathrm{TiO}_{2}, \mathrm{Cr}_{2} \mathrm{O}_{3}-5 \mathrm{SiO}_{2}-3 \mathrm{TiO}_{2}$, and $\mathrm{TiO}_{2}$ coatings from micro-structured and nanostructured powders. Performance and characteristics of VPS-applied coatings are generally superior or equal to those of APS-applied coatings. Nanostructured powders are found to be more sensitive to the thermal spray process used, as compared to conventional micro-structured powders. VPS provide a better environment for applying nanostructured oxide ceramic materials, as compared to APS. The superior properties of coatings applied from nanostructured powders seem to be associated with coatings that have retained a nanostructure, i.e. a bimodal structure composed of partially or unmolten particles, combined with fully molten regions. 
Nanostructured alumina-titania coatings were produced by plasma spray of reconstituted nanostructured powders, using optimized processes, defined by a critical plasma spray parameter [53]. Physical and mechanical properties, including density, hardness, indentation, crack growth resistance, adhesive strength, spallation resistance in bend and cup tests and resistance to abrasive and sliding wear. These properties were also examined as a function of critical plasma spray parameter (CPSP) and compared with the Mtco-130 (conventional) coating. Superior properties of nano coatings are reported as compared to their conventional counter parts. The superior properties are associated with coatings that have a retained nanostructure, especially with partial melting of the nanostructured powders.

Jin-hong Kim et al [54] have successfully developed thermal sprayed nanostructured WC-Co wear resistant coatings and the resultant coatings showed significant improvement of wear resistance in comparison with the conventional counterparts. Micro structural in homogeneity of the conventional $\mathrm{Cr}_{2} \mathrm{O}_{3}$ based solid-lubricant coatings was successfully solved by utilizing nanostructured feedstock powder developed. Nanostructured and conventional zirconia coatings were deposited by atmospheric plasma spraying and the thermal shock resistance of as-sprayed coatings was investigated by the water quenching method [55]. The results showed that the nanostructured as-sprayed coatings possessed better thermal shock resistance then the conventional coating. This phenomenon is explained in terms of the difference in microstructure and micro-structural changes occurring during thermal shock cycling. During the thermal shock cycling, the formation of vertical cracks, inter-granular fracture as well as the tetragonal to monoclinic transformation which occurred on the coating surface also make a contribution to the better thermal shock resistance of the nanostructured zirconia coatings.

R. Soltani et al. [56] have successfully deposit nanostructured coatings of $\mathrm{Y}_{2} \mathrm{O}_{3}-\mathrm{PSZ}$ (partially stabilized zirconia) from nano-particulate powder feedstock. Wear testing of nanostructured and conventional coatings showed that the nanostructured coating had a lower coefficient of friction and had lower wear loss under discontinuous testing conditions.

Xinhua Lin et al. [57] have studied the effects of temperature on tribological properties of nanostructured and conventional $\mathrm{Al}_{2} \mathrm{O}_{3}-3$ wt \% $\mathrm{TiO}_{2}$ coatings deposit by atmosphere plasma spraying. The tribological properties of both coatings against silicon nitride ball were examined in the temperature range from room temperature to $600^{\circ} \mathrm{C}$. The wear resistance of the nanostructured coating was found better at high temperature as compared to their conventional counterpart. 


\section{CONCLUSIONS}

1. Hot corrosion \& erosion are serious problems in power generation equipment, in gas turbines for ships and aircrafts and in other energy conversion and chemical process systems and should be either totally prevented or detected at an early stage to avoid catastrophic failure.

2. The coal used in Indian power stations has large amounts of ash (about 50\%), which contain abrasive mineral species such as hard quartz (up to $15 \%$ ), which increase the erosion propensity of coal.

3. Hot corrosion is often divided into two forms of attack: Type I or High temperature hot corrosion (HTHC) above about $900^{\circ} \mathrm{C}$, and Type II or Low temperature hot corrosion (LTHC), between about $700^{\circ} \mathrm{C}-750^{\circ} \mathrm{C}$.

4. Application of a proper combination of preventive approaches should lead, in practice, to a significant decrease in the number of failures due to hot corrosion.

5. Hot corrosion and Erosion preventive methods to the existing environment are (a) change of metal i.e. use of super alloy (b) use of inhibitors and (c) use of coatings.

6. The development of modern coal fired power generation systems with higher thermal efficiency requires the use of construction materials of higher strength and with improved resistance to the aggressive service atmospheres. These requirements can be fulfilled by protective coatings.

7. At present, methods to minimize the extent of hot corrosion and erosion have been identified; however considerable research effort is needed for application and quantitative evaluation of these methods under consideration of interest in the coal-gasification processes.

\section{ACKNOWLEDGEMENT}

The authors wish to thank All India Council for Technical Education (A.I.C.T.E.), New Delhi, India for providing National Doctoral Fellowship (NDF) to Mr. Vikas Chawla (corresponding author).

\section{REFERENCES}

1. A.S. Khanna, "Introduction to high temperature oxidation and corrosion", ASM International, ISBN 0-87170-762-4, SAN: 204-7586, 2002, pp 1-322.

2. P.V. Ananthapadmanabhan, K.P. Sreekumar, K.V. Muraleedharan, N. Venkatramani, “ Plasma-sprayed composite coatings for high temperature applications", Surface \& Coating Technology, Vol. 49, 1991, pp 62-66. 
3. John Stringer, "High temperature corrosion problems in coal based power plant and possible solutions", Proceedings International conference on corrosion 'CONCORN' 97, Dcember 3-6, Mumbai, India, pp 13-23.

4. K. Natesan, "Corrosion performance of materials in coal-fired power plants", Proceedings International conference on corrosion 'CONCORN' 97, Dcember 3-6, Mumbai, India, pp 24-35.

5. P.R.Krishnamoorthy, S. Seetharamu and P.Sampathkumaran, "Influence of the mass flux and impact angle of the abrasive on the erosion resistance of materials used in pulverized fuel bends and other components in thermal power stations", Wear, Vol. 165, 1993, pp 151-157.

6. B.A. Landry, J.D. Hummel, H.W. Nelson et al, "A review of available information on corrosion and deposition in coal and oil fired boilers and gas turbines", ASME research committee, Pergamon press, The American society of mechanical engineers, New York, pp 1-197.

7. Robert A. Rapp, "Chemistry and electrochemistry of hot corrosion of metals", materials science and engineering, 87, 1987, 319-327.

8. M.H. Li, X.F.Sun, J.G.Li, Z.Y. Zhang, T. Jin, H.R. Guan, Z.Q. Hu, Oxid. Metals, Vol.59 $(5 / 6)(2003)$.

9. Kevin J. Stein, Brian S. Schorr, Arnold R. Marder, "Erosion of thermal spray MCr-Cr C cermet coatings", Wear, Vol. 224, 1999, pp 153-159.

10. V. Higuera Hidalgo, J. Belzunce Verela, A. Carriles Menendez, S. Poveda Martinez, "High temperature erosion wear of flame and plasma sprayed nickel-chromium coatings under similated coal-fired boiler atmospheres", Wear, VO1.247, 2001, pp 214-222

11. R. Viswanathan, " Damage mechanism and life assessment of high-temperature components", ASM International, 1989, ISBN: 0-87170-358-0, pp 1-483.

12. R. A. Rapp and K. S. Goto, Symposium on Fused Salts, J. Braunstein and J. R. Selman (Eds.), The Electrochemical Society, Pennington, N. J., (1981),pp.159.

13. J.J Wells , F. Wigley, D.J Foster, W.R Livingston, W.h Gibb, J. Williamson, "The nature of mineral matter in a coal and the effects on erosive and abrasive behavior", Fuel Processing Technolgy, Vol.86(2005),pp. 535-550.

14. Buta Singh Sidhu and S. Prakash, "Evaluation of the behavior of shrouded plasma spray coatings in the platen superheater of coal-fired boilers", Metallurgical \& Materials Transactions, Vol. 37A, 2006,pp 1927.

15. T.S. Sidhu, R.D. Agarwal, S. Prakash, "Hot corrosion of some super alloys and role of high-velocity oxy-fuel spray coatings", Surface Coatings \& Technology, Vol. 198, 2005,pp 441-446.

16. J. L He, K.C. Chen, C.C Chen, A.Leyland, and A. Matthews, "Cyclic Oxidation Resistance of Ni-Al Alloy Coatings Deposited on Steel by a Cathodic Arc Plasma Process,” Surf. Coat. Technol.,Vol. 135, 2001, pp. 158-65. 
17. A.S. Khana, S. K. Jha, "Degradation of materials under hot corrosionconditions", Trans. Indian Inst. Met. , 51 (5), 1998, 279-90.

18. Robert A. Rapp, "Hot corrosion of materials: a fluxing mechanisms", Corrosion Science ,44, 2002, 209-221.

19. Vikas Chawla, S. Prakash, D. Puri, Buta Singh, Manoj Singla, "Hot corrosion-a review", Global Conference on Production \& Industrial Engineering, March 2007, organized by Dr. B.R. Ambedkar Institute of Technology, Jalandhar (India).

20. N. Eliaz, G. Shemesh, R.M. Latenision, "Hot corrosion in gas turbine components", Engineering failure analysis, 9, 2002, 31-43.

21. B. Q. Wang, G. Q. Geng and A.V. Levy, Surface \& Coating Technology, Vol. 54-55, (1992), pp.529-35.

22. Y.T. Pei, D. Galvan, J. Th. M. De Hosson, A. Cavaleiro, "Nanostructured TiC/a-C coatings for low friction and wear resistant application", Surface \& Coatings Technology, Vol. 198, 2005, pp 44-50.

23. S.B. Mishra, S. Prakash, K. Chandra, "Studies on erosion behavior of plasma sprayed coatings on a Ni-based super alloy", Wear, Vol. 260, 2006, 422-432.

24. Kevin J. Stein, Brien S. Schorr, Arnold R. Marder, "Erosion of thermal spray MCr$\mathrm{Cr}_{3} \mathrm{C}_{2}$ ", Wear, Vol. 224, 1999, pp 153-159.

25. R. Norling, I. Olefjord, "Erosion-corrosion of Fe- and Ni-based alloys at 550C", Wear, Vol.254, 2003, pp 173-184.

26. M.M. Stack, S. Lekatos, F.H. Stott, "Erosion-corrosion regimes: number, nomelclature and justification", Tribology Journal, Vol. 28, No. 7, 1995, pp 445-451.

27. S. Prakash, S. Singh, B. S. Sidhu and A. Madeshia, (2001), "Tube Failures in Coal Fired Boilers," Proc. National Seminar on Advances in Material and Processing, Nov., 9-10, IITR, Roorkee, India, pp. 245-253.

28. Chen, H. C., Liu, Z. Y. and Chuang, Y. C., (1993), "Degradation of Plasma-Sprayed Alumina and Zirconia Coatings on Stainless Steel During Thermal Cycling and Hot Corrosion," Thin Solid Films, Vol. 223, No. 1, pp. 56-64.

29. N. Priyantha, P. Jayaweera, A. Sanjurjo, K. Lau, K. Krish, "Corrosion-resistant metallic coatings for applications in highly aggressive environment", Surface \& Coating Technology, Vol. 163-164, 2003, 31-36.

30. M.G. Hocking, "Coating resistant to erosive/corrosive and severe environment", Surface Coatings \& Technology, Vol. 62, 1993, p 460-466.

31. L. Fedrizzi, S. Rossi, R. Cristel, P.L. Bonora, "Corrosion and wear behavior of HVOF cermet coatings used to eplace hard chromium”, Electrochemica Acta, Vol 49, 2004, pp 2803-2814.

32. .R. Heath, P. Heimgartner, G. Irons, R. Miller, and S. Gustafsson, Material Science Forum, Vol. [251]-54, [1997], 809-816. 
33. P.Bansal, N. P. Padture, A. Vasiliev, " Improved interfacial properties of $\mathrm{Al}_{2} \mathrm{O}_{3}$ $13 \mathrm{wt} \% \mathrm{TiO}_{2}$ plasma sprayed coatings derived from nanocrytalline powders", Acta Materialia, 2003, Vol.51, pp.2959-2970.

34. B. liang, C. Ding, "Thermal shock resistance of nano-structured and conventional zirconia coatings deposited by atmospheric spraying", Surface \& Coating Technology journal,2005,Vol.197,pp.85-192.

35. Buta singh Sidhu, S. Prakash ., "Evaluation of the corrosion behaviour of plasma sprayed $\mathrm{Ni}_{3} \mathrm{Al}$ coatings on steel in oxidation and molten salt environments at $900^{\circ} \mathrm{C}$, , Surface \& coatings technology, 166, Vol. 2003, pp. 89-100.

36. T.S. Sidhu, S. Prakash and R.D. Agrawal, "Hot corrosion performance of a NiCr coated Ni-based alloy", Scripta Materialia, Vol.55, 2006, pp.179-182.

37. S.B. Mishra, K. Chandra, S. Prakash, B. Venkataraman, "Characterization and erosion behaviour of a plasma sprayed $\mathrm{Ni}_{3} \mathrm{Al}$ coating on a Fe-based superalloy", Materials Letters, Vol.59, 2005, pp. 3694-3698.

38. H. Singh, S. Prakash, D. Puri, "Some observations on the high temperature oxidation behaviour of plasma sprayed Ni3Al coating",Materials Science \& Engineering, Vol....., 2006, PP......

39. Harpreet Singh, D. Puri, S. Prakash, "Some studies on hot corrosion performance of plasma sprayed coatings on a Fe-based superalloy", Vol.192, 2005, pp. 27-38.

40. Hazoor Singh Sidhu a, *, Buta Singh Sidhu b, S. Prakash, "The role of HVOF coatings in improving hot corrosion resistance of ASTM-SA210 GrA1 steel in the presence of $\mathrm{Na}_{2} \mathrm{SO}_{4}-\mathrm{V}_{2} \mathrm{O}_{5}$ salt deposits", Surface \& Coatings Technology, Vol. 200, 2006, pp. 5386 $-5394$.

41. S. Paldey, S. C. Deevi, "Single layer and multilayer wear resistant coatings of (Ti,Al): a review", Materials Science \& Engineering, Vol: A 342, 2003, pp 58-79.

42. L.A. Dobrzanski, K. Lukaszkowicz, A. Zarychta, L. Cunha, "Corrosion resistance of multilayer coatings deposited by PVD techniques onto the brass substrate", Journal of Materials Processing Technology, Vol. 164-165, 2005, pp 816-821.

43. In S. Choi, Jong C. Park, "The corrosion behavior of TiAlN coatings prepared by PVD in a hydrofluoric gas atmosphere", Surface Coatings \& Technology, Vol. 131, 2000, pp. 383-385.

44. Sugehis Liscano, Linda Gil, O.A. Leon, Marlon Cruz, Mariana H. Staia, "Corrosion performance of duplex treatments based on plasma nitriding and PAPVD TiAlN coating ", Surface Coatings \& Technology, Vol. 201, 2006, 4419-4423.

45. R. Rodriguez-Baracaldo, J.A. Benito, E.S. Puchi-Cabrera, M.H. Staia, "High temperature wear resistance of (TiAl)N PVD coating on untreated and gas nitrided AISI H13 steel with different heat treatments", Wear, Vol. 262, 2007, 380-389.

46. W. Kalss, A. Reiter, V. Derfinger, C. Gey, J.L. Endrino, "Modern coatings in high performance cutting applications", International Journal of Refractory Metals \& Hard Materials, Vol. 24, 2006, pp 399-404. 
47. S. Tsipas, J.M. Brossard, M.P. Hierro, J.A. Trilleros, L. Sánchez, F.J. Bolívar, F.J. Pérez, "Al-Mn CVD-FBR protective coatings for hot corrosion application", Surface \& Coatings Technology, Vol. 201, 2007, pp.4489-4495.

48. F.J. P'ereza,U, F. Pedrazaa, M.P. Hierroa, P.Y. Hou, "Adhesion properties of aluminide coatings deposited via CVD in fluidised bed reactors_CVD-FBR/on AISI 304 stainless steel", Surface and Coatings Technology, Vol. 133-134, 2000, pp..338-343.

49. P.Bansal, N. P. Padture, A. Vasiliev, "Improved interfacial properties of $\mathrm{Al}_{2} \mathrm{O}_{3}$ $13 \mathrm{wt} \% \mathrm{TiO}_{2}$ plasma sprayed coatings derived from nanocrytalline powders", Acta Materialia, Vol.51 (2003), pp.2959-2970.

50. L.L. Shaw, D. Goberman, R. Ren, M. Gell, S. jiang, Y. Wang, T.D. Xiao, P.R. Strutt,” The dependency of microstructure and properties of nanostructured coatings on plasma spray conditions", Surface Coatings \& Technology, Vol. 130 (2000),pp. 1-8.

51. Chuanxian Ding, Huang Chen, Xuanyong Liu, Yi Zeng, "Plasma sprayed nanostructured zirconia coatings for wear resistance", Thermal Spray 2003: Advancing the science \& applying the technology, (Ed.) C. Moreau and B. Marple, Published by ASM International, Materials Park, Ohio, USA, (2003), 455-458.

52. L. Leblanc, "Abrasion and sliding wear of nanostructured ceramic coatings", Thermal Spray 2003: Advancing the science \& applying the technology, (Ed.) C. Moreau and B. Marple, Published by ASM International, Materials Park, Ohio, USA, (2003), 291-299.

53. E. H. Jordan, M. Gell, Y.H. Sohn, D. Goberman, L. Shaw, S. Jiang, M. Wang, T.D. Xiao, Y. Wang, P. Strutt, "Fabrication and evaluation of plasma sprayed nanostructured alumina-titania coatings with superior properties", Materials Science \& Engineering, Vol. [A 301], (2001), 80-89.

54. Jin-hong Kim, Hyun-seok Yang, Kyeong-ho Baik, Byeung Geun Seong, Chang-hee Lee, Soon Young Hwang, "Development and properties of nanostructured thermal spray coatings", Current Applied Physics, Vol. [6], issue 6, (2006), 1002-1006.

55. Bo Liang, Chuanxian Ding, "Thermal shock resistances of nanostructured and conventional zirconia coatings deposited by atmospheric plasma spraying", Surface Coatings \& Technology, Vol. [197], (2005), 185-192.

56. R. Soltani, T.W. Coyle, J. Mostaghimi, "Wear resistance of nanostructured thermal barrier coatings", Thermal Spray 2003: Advancing the science \& applying the technology, (Ed.) C. Moreau and B. Marple, Published by ASM International, Materials Park, Ohio, USA, (2003), 1535-1540.

57. Xinhua Lin, Yi Zeng, Chuanxian Ding, Pingyu Zhang, "Effects of temperature on tribological properties of nanostructured and conventional $\mathrm{Al}_{2} \mathrm{O}_{3}-3 \mathrm{wt} \% \mathrm{TiO}_{2}$ coatings", Wear, Vol.[256], (2004), 1018-1025. 